\title{
"RENTIER STATES" OR THE RELATIONSHIP BETWEEN REGIME STABILITY AND EXERCISING POWER IN POST-SOVIET CENTRAL ASIA
}

\author{
PÁL ISTVÁN GYENE ${ }^{1}$ \\ ${ }^{1}$ PhD candidate, Corvinus University of Budapest \\ Assistant Professor, Budapest Business School, Faculty of International Management and \\ Business \\ E-mail: gyene.pal@kkfk.bgf.hu
}

\begin{abstract}
The paper intends to give an insight into the relations of the economic and political systems of the Central Asian republics using the theoretical framework of the "rentier economy" and "rentier state" approach. The main findings of the paper are that two (Kazakhstan and Turkmenistan) of the five states examined are commodity export dependent "full-scale" rentier states. The two political systems are of a stable neo-patrimonial regime character, while the Kyrgyz Republic and Tajikistan, poor in natural resources but dependent on external rents, may be described as "semi-rentier" states or "rentier economies". They are politically more instable, but have an altogether authoritarian, oligarchical "clan-based" character. Uzbekistan with its closed economy, showing tendencies of economic autarchy, is also a potentially politically unstable clan-based regime. Thus, in the Central Asian context, the rentier state or rentier economy character affects the political stability of the actual regimes rather than having a direct impact on whether power is exercised in an autocratic or democratic way.
\end{abstract}

Keywords: rentier states, rentier economy, post-soviet central Asia

JEL-codes: P1, P16

\section{Introduction}

Over the past decades, theories concerning rentier economies and rentier states have received increasing attention in political science and political economy. The theoretical framework constructed on the basis of the oil monarchies of the Gulf States has greatly contributed to 
explaining why the neo-patrimonial way of exercising power has survived to this modern day. It is no surprise that theories about rentier economies have been applied to regions of the world outside the Middle East, with the post-Soviet Central Asian republics among them. This paper gives a critical analysis, attempting to answer the following questions:

- To what extent is it acceptable to qualify the five post-Soviet Central Asian republics as "rentier states", or even as "rentier economies"? To what extent is each national economy open and export dependent? To what extent does the survival of the regime depend on outside resources, and how much direct control do they have over their distribution?

- If the "rentier state" or the "rentier economy" character is empirically proven, is it related to the personality-centered exercise of power or perhaps to the degree of political suppression or regime stability?

- If this link does exist, can it be understood as a causal relationship? In other words, does the rentier state result in stronger political oppression and/or more regime stability?

One important finding in the paper is that two of the five states examined, namely Turkmenistan and Kazakhstan, are very close to the ideal type of the "rentier state". Although Kyrgyzstan and Tajikistan are politically less stable, they may be described as "rentier economies" greatly dependent on outside resources. It is also argued that Uzbekistan does not meet the criteria of a rentier state or a rentier economy, although Uzbek political elite groups are also guided by some form of the rentier logic. It is thus shown that in the case of these republics the authoritarian-neo-patrimonial nature of exercising power is not primarily due to their "rentier state" character. In the Central Asian context, the "rentier state" character appears to have a direct and fairly unambiguous impact on is political stability. Of the regimes based on the rentier logic, those that are rich in natural resources clearly perform better for political stability than those that have more modest economic resources.

\section{The rentier economy and rentier state as ideal-typical categories of analysis}

The rentier economy and rentier state as ideal-typical categories of analysis were first elaborated in the 1970s, based primarily on the examples of the oil producing and exporting 
Gulf States. In economy, rent is defined as earnings originating directly from selling natural resources rather than from production (Marshall cited by Beblawi 1990: 85).

Consequently, a "rentier economy" is a national economy where the larger part of state revenues typically comes from exporting natural resources, for example oil. The rentier economy characteristically depends on some natural resource, although it could also rely on a different type of outside resource, for example, guest workers' remittances. According to Luciani, the main distinguishing feature of a "rentier economy" is not primarily its exports of raw materials but rather the fact that national revenues originate from outside sources, rather than from domestic productive sectors (Luciani 1990: 71). A "rentier economy" does not necessarily lead to the emergence of a "rentier state". In the case of a rentier state, outside earnings do not go directly to members of the society the way they do for example when guest workers make remittances, but a narrow elite, the government in fact, controls their distribution. During the 80s in the oil monarchies of the Middle East, for example, 2 or 3 per cent of the total population enjoyed full control over oil export revenues, making up as much as 80 or 90 per cent of the countries' GDP (Beblawi 1990: 89). Luciani sees the main social function of rentier states in the social allocation of earnings; thus on the level of terminology he suggests a distinction between allocative and productive states (Luciani 1990: 71). In allocative states, the government does not levy taxes on citizens; on the contrary: every citizen is entitled to a certain income and other benefits. This is exactly why he does not classify rentier economies dependent on guest workers' remittances as allocative states, since in this case the only, indirect, way the state can generate income from those sums is by imposing taxes on the families living at home (Luciani 1990: 72). The degree of the state's allocativity or productivity is best reflected by the ratio of government social spending to the GDP, which in the oil exporting Arab countries of the Middle East was as high as 30 to 50 per cent in the 1970s and 80s (Luciani 1990: 72-74).

Using the examples of the non-oil producing states of the Middle East, namely Egypt, Tunisia and Morocco, Beblawi uses the term "semi-rentier", which is a rough equivalent of Luciani's "rentier economy". These are countries where a considerable part of the GDP is made up of revenues coming from abroad, but not as payment for exports of natural resources. These earnings may originate from foreign military or financial aid, transit fees for using pipelines leasing the country's infrastructure by allowing other states to use its airports or ports for establishing military bases, and last but not least, guest workers' remittances.

It appears that the rentier character of a state is related to its political system and extent of political stability. In those contexts where state revenues primarily come from taxing the 
society's productive layers, a long-term regime cannot reign without some form of democratic legitimation, as illustrated by the well-known historical slogan "No taxation without representation" (Luciani 1990, 75). In allocative or rentier states as citizens are economically dependent on the state rather than the other way round, the political leadership does not "need" democratic legitimation. Based on the logic of "no representation without taxation" in several cases allocative regimes do not ensure even the semblance of democratic representation. For the functioning of the vertical patron-client logic of "rentier states", a neopatrimonial authoritarian type of political structure provides a more suitable framework. Characteristically, the rentier state enhances the authoritarian features of the political system. This is how the state's rentier character contributed to conserving the apparently rather anachronistic patrimonial monarchies of the Gulf States (Luciani 1990: 79-80).

While there is a professional consensus about the negative effect of the "rentier state" on democratisation, over the past decades there has been a prolific debate about the relationship of the rentier character and regime stability. In the 2000s, primarily based on the studies of Collier and Hoeffler (2000) and de Soysa (2000), who examined the Middle East and countries of Sub Saharan Africa, it has become a generally accepted view that political instability and thus the danger of civil war has increased due to natural resources, especially the abundance of easy to exploit hydrocarbon fuels and minerals, and especially in poor developing countries. ${ }^{1}$ In contrast, research including findings about South Eastern Asia suggests that hydrocarbons and other minerals strengthen the political system's stability, especially in authoritarian regimes (Colgan 2015), while in poor developing countries they may undermine the stability of democratic political systems (Smith 2015: 2). Michael L. Ross identifies a number of mechanisms through which rentier type authoritarian regimes may strengthen their power. In addition to the effects already examined in the literature (i.e. that through tax evasion the government is less accountable and large-scale social spending), Ross draws attention to the fact that rentier regimes rich in natural resources are able to effectively hamper the development of non-state dependent civil society (Ross 2001: 332-336). Gawrich and Franke are emphasizing that in a rentier state the middle classes, in particular, are

\footnotetext{
${ }^{1}$ According to game theoretical argumentation, geographically concentrated fixed locations of mineral deposits may be an attractive target for any armed rebel groups. They can capture them at relatively low investment costs, and for a long time afterwards, these resources will finance the maintenance of the conflict. Le Billon has found that concentrated mineral resource deposits located in a country's central region contribute to the probability of a coup-type takeover, while those on the peripheries add to the probability of separatist type of armed conflicts. (Le Billon 2001: 573).
} 
missing. Instead of the middle class and traditional elites, there is an egoistic "rentier class" of civilian technocrats of public administration (Gawrich - Franke 2011a: 14.).

As illustrated by remittances, in semi-rentier states the government's role in the distribution of earnings coming from outside is not as exclusive as it is in rentier states. Therefore, semi-rentier regimes need at least the semblance of democratic legitimation much more and tend to be politically less stable than neo-patrimonial rentier regimes. Nevertheless, semi-rentier states also have wide clienteles dependent on the government, often appearing in the form of an artificially inflated, corrupt bureaucracy (Beblawi 1990: 97).

\section{Rentier states and rentier economies in post-Soviet Central Asia}

Wojciech Ostrowski argues that the analytical framework based on the notions of the "rentier" and "semi-rentier" state is easily applicable to the five post-Soviet successor states in Central Asia. He points out that the Central Asian rentier economy and rentier state character is fundamentally defined by two factors. On the one hand, as a heritage of the Soviet past, it can be attributed to the fact that within the Soviet Union the Central Asian republics were charged with the task of providing industrial centers in Slavic regions with raw materials, such as oil, cotton, etc. On the other hand, their rentier character was further intensified by the price liberalization following the Soviet Union's collapse, which resulted in drastic price rises and motivated the countries concerned to introduce some economic de-diversification (Ostrowski 2011: 285-286).

Unfortunately, however, Ostrowski does not clearly define what he means by a "rentier state" and a "rentier economy." Consequently, although the main conclusions of his study are acceptable, his qualification of individual Central Asian Republics seems rather arbitrary. The literature offers a wide variety of methodological approaches to the conceptualisation of the "rentier state" and "rentier economy" as analytical categories. It is a generally used method to consider the proportion of oil and other minerals (or occasionally of agricultural raw materials) within the country's full exports. The drawback of this method is that in itself it does not reflect the weight of the given mineral in the country's economy, as for example its share in the GDP. Thus, the sectorial division of exports should be examined together with the degree of the country's foreign trade openness. Another frequently applied index is the ratio of oil and mineral export revenues to the GDP. Jeff D. Colgan, for example, regards as "petrostate" any state where per capita hydrocarbon production and export revenues exceed a 
hundred dollars a year (Colgan 2015: 4). Smith adds that per capita oil income gives us a realistic picture only if it is compared to the performance of the given national economy's other sectors. Therefore, he recommends using a modified measure calculated as a ratio of per capita oil income and per capita GDP (Smith 2015: 6). Besides state revenues, when identifying the rentier character of a state it is also worth examining the extent of state expenditure, of which the percentage of government investments into the welfare or law enforcement institutions in the annual GDP may inform us.

In line with the literature review, this paper will give an overview of the foreign trade structure of Central Asian republics, with special emphasis on the rate of hydrocarbon fuels and other minerals ${ }^{2}$ as well as of the degree of foreign trade openness of the countries concerned.

On this basis, it is possible to calculate the weight of mineral exports and other external resources (e.g. guest workers' remittances) in each country's economy. Wherever revenues from hydrocarbons and minerals are close to, or even exceed 50 per cent of the annual GDP, we may safely assume that it is a rentier state. However, if the larger part of the GDP is composed of guest workers' remittance, foreign aid or leasing fees, it is usually more adequate to use the labels "semi-rentier state" or "rentier economy". Comparing all these data with the ratio of government spending to the GDP, we can conclude whether a republic should be seen as a rentier state, a rentier economy, or neither.

After the economic collapse of the 1990s, measured in absolute figures, the first decade of the new millennium saw a considerable expansion of the Central Asian republics' foreign trade. This however, did not necessarily mean that these national economies were becoming more open, as the rate of their own economic growth was close to, or occasionally even exceeded, the growth in exports and imports. Thanks to the increase in the price of energy and raw materials between 1999 and 2008, and a repeated increase after 2009, the volume of exports from the three net energy exporters, Kazakhstan, Turkmenistan and Uzbekistan, showed a spectacular rise of 50 to 100 per cent compared to the value of their imports. The same trends, however, had a negative impact on the exports and foreign trade balance of the two net energy importers, Kyrgyzstan and Tajikistan, primarily because of the rising fuel

\footnotetext{
${ }^{2}$ I do not regard exports of agricultural raw materials of special importance from this respect, as in the literature (De Soysa 2000; Le Billon 2001) there seems to be a consensus that the dominance of the agrarian sector, being labor rather than capital intensive, in the national economy does not lead to the emergence of the "rentier" character. In the sectoral analyses of Kazakhstan and Kirgizstan's foreign trade, I used mostly COMTRADE statistics, while for the three other republics I had to rely on national statistical data, which are considered far more unreliable (they are closer to intelligent guesses than genuine statistics).
} 
prices, higher costs of transport and more expensive imported energy (Mogilevskii 2012: 712).

Table 1. Central Asian countries' foreign trade openness

Exports (million USD) - (\%GDP)

\begin{tabular}{|c|r|c|r|c|c|c|}
\hline & \multicolumn{1}{|c|}{$\mathbf{2 0 0 0}$} & $\mathbf{2 0 0 0}$ & \multicolumn{1}{|c|}{$\mathbf{2 0 1 0}$} & $\mathbf{2 0 1 0}$ & \multicolumn{1}{c|}{$\mathbf{2 0 1 2}$} & $\mathbf{2 0 1 2}$ \\
\hline Kazakhstan & 10353,71 & 57 & 65077,56 & 44 & 96882.56 & 48 \\
\hline Kyrgyzstan & 573,18 & 42 & 2471,7 & 52 & 3202.51 & 48 \\
\hline Tajikistan & 799,36 & 65 & 865,75 & 15 & 1644.16 & 22 \\
\hline Turkmenistan & 2774 & 96 & 17234,44 & 78 & 25760.63 & 73 \\
\hline Uzbekistan & 3383,4 & 25 & 12452,71 & 32 & 14251.92 & 28 \\
\hline
\end{tabular}

Source: World Bank

In Kazakhstan and Turkmenistan, the oil sector has obtained an even more dominant position within the economy than before their independence. With the Kashagan oil fields discovered in the north west of the country, Kazakhstan owns the largest untapped oil resource outside the Middle East (Afanasyeva 2012) and is the $19^{\text {th }}$ most important oil producing country, while its stocks of natural gas are also remarkable. Within Kazakhstan's exports the share of oil has increased from 25 per cent in the mid-1990s to nearly 50 per cent by the early 2000 s. In addition, Kazakhstan is also one of the leading producers of copper, zinc and uranium (Olcott 2010: 169).

With the 2006 discovery of the giant South Yolotan and Osman gas fields, Turkmenistan's natural gas stocks are regarded as the sixth largest in the world, while following Russia, the USA and Iran, the country is the fourth most important natural gas exporter. Today the share of fuels in Turkmenistan's exports is already over 80 per cent. In the region, Turkmenistan has seen the largest, almost dramatic expansion in its foreign trade over the past decade. Between 2000 and 2010, the volume of exports tripled, while imports almost quadrupled. Because of these developments, the value of trade is more than 50 per cent of the GDP. Thanks to the dynamic growth of energy exports, in the period examined the country's trade balance always showed a considerable surplus of over 20 per cent of the GDP (Mogilevskii 2012: 23). Thus, out of the five Central Asian republics, Turkmenistan is the one that seems closest to the oil monarchies of the Middle East representing the "classic" rentier states.

The 2000s have brought Uzbekistan a dynamic growth in foreign trade: export output has nearly tripled, while imports have doubled. Thanks to the faster expansion of exports than 
imports, the country has accumulated a considerable foreign trade surplus amounting to about 5 per cent of the GDP, which is still certainly more modest than that of Kazakhstan or Turkmenistan. As a result, by the end of the decade, the openness of the Uzbek economy rose to some 20 per cent from an estimated 12 per cent in 2002. In spite of this development, the Uzbek economy appears to be the least dependent on its foreign trade and the least open national economy in the region (Mogilevskii 2012: 26), which strongly modifies Ostrowski's image of Uzbekistan as a "rentier state".

Uzbek exports are still dominated by raw materials. Combined, natural gas, non-ferrous metals and cotton make up 67.6 per cent of all exports, with no major fluctuation since 2000 . Within raw materials, it is remarkable that the share of carbon fuels has almost doubled, rising from 12 per cent in 2000 to 25 per cent by 2010 . The country that used to aim at being selfsufficient for fossil fuels has developed into a major natural gas exporter on the regional level. Replacing cotton, by now natural gas has become Uzbekistan's number one export item. In Uzbek agriculture and agrarian export, the share of fruit and vegetables has been increasing against cotton. The exports of various non-ferrous metals, primarily gold represent a stable 25 per cent of all exports (Anderson - Klimov 2012: 18-20).

Table 2. Share of hydrocarbon fuels and minerals in Central Asian states' export and GDP.

\begin{tabular}{|l|c|c|c|c|}
\hline & \multicolumn{2}{|c|}{$\begin{array}{c}\text { Income from exports of } \\
\text { hydrocarbon fuels and } \\
\text { minerals within the full } \\
\text { exports }\end{array}$} & $\begin{array}{l}\text { hydrocarbon fuels and } \\
\text { minerals (as a percentage of } \\
\text { annual GDP) }\end{array}$ \\
\hline & $\mathbf{2 0 0 0}$ & $\mathbf{2 0 1 0}$ & $\mathbf{2 0 0 0}$ & $\mathbf{2 0 1 0}$ \\
\hline Kazakhstan & $82 \%$ & $91 \%$ & $47, \%$ & $40 \%$ \\
\hline Kyrgyzstan & $43 \%$ & $60 \%$ & $18 \%$ & $31 \%$ \\
\hline Tajikistan & $60 \%$ & $80 \%$ & $38 \%$ & $12, \%$ \\
\hline Turkmenistan & $80 \%$ & $83 \%$ & $55 \%$ & $64, \%$ \\
\hline Uzbekistan & $15 \%$ & $37 \%$ & $3 \%$ & $11 \%$ \\
\hline
\end{tabular}

Source: COMTRADE, Agency of Statistics of the RK, Agency on Statistics of the RT, National Statistical Committee of the $K R$, State Committee of the $R U$ on Statistics, State Committee of Turkmenistan on Statistics, and the author's calculations based on Mogilevskii's (2012) data. The percentages are only estimates. 
Kyrgyzstan and Tajikistan were the two poorest republics in the Soviet Union, and even in the year when the Soviet Union collapsed, 35 per cent of the Kyrgyz Republic's and nearly 46 per cent (almost half!) of the Tajik Republic's budget came from subsidies from the Moscow centre (Collins 2006: 157). Unlike the other three republics, which in fact gained from the market liberalization of resource prices, economically Kyrgyzstan and Tajikistan were probably the countries hardest hit by the Soviet collapse. These states have accumulated considerable foreign trade deficits over the last two decades, which they have been able to finance from the remittances of the large numbers of their citizens working abroad as guest workers, as well as from incomes from informal cross border trade and re-exportation, international aids, and in the case of Tajikistan, supposedly also from the transit trade of illegal narcotics. (Mogilevskii 2012: 7-12). As Ostrowski points out, Kyrgyzstan and Tajikistan started to be like the countries of the "global south" - excluded from the "neoliberal project" and integrated into the global world economy mostly through a shadow economy based on money laundering, migration and drug dealing (Ostrowski 2011: 286).

Industrially, Tajikistan was the least developed republic in Soviet times, and on top of that, the civil war ravaged most of the existing minimal industrial infrastructure. In our days, the main elements of Tajik industry are generating electric energy based on hydroelectric power stations and aluminium production, which requires significant amounts of electric energy. The significance of the Tursunzoda Aluminum Company on the Vakhsh River is indicated by the fact that half of Tajikistan's (official) export earnings come from aluminium produced in this region and that this plant in itself uses some 40 per cent of the electric energy generated in the country (Olcott 2005: 115).

In the absence of strong industry or well-working agriculture, even according to cautious estimates the rate of employment is over 40 per cent. In the decades following the civil war the Tajik population had three main sources of income: the lucky ones could work for an NGO active in the country, others lived on remittances, and still others joined the illegal drug trade, in fact the most stable pillar of the country's economy (Olcott 2005: 113). Today some 1.5 million Tajiks work abroad. Tajikistan has the highest proportion of migrants to the full population (every fifth citizen) in the former Soviet Union, as well as in the whole world (Erlich 2006). In 2005, their remittances totaled 600 million dollars, and it is estimated that even today remittances account for some 42 per cent of the GDP (World Bank 2012a). At least 15 per cent of Tajik households live exclusively on remittances (Nazriev and Manzarshoeva 2009). 
The second comparably significant source of income is the drug trade. Tajikistan shares a 1,800 kilometre long, poorly protected border with the world's number one heroin and opium grower, Afghanistan. It is estimated that as much as 90 tons of heroin, some 30 per cent of Afghanistan's output, crosses the Tajik-Afghan border on its way to Russia. Earnings from the drug trade may amount to 30 to 50 per cent of the annual Tajik GDP. Thus, unlike in Mexico, after the civil war the drug trade made a special contribution to the stabilization of the Tajik central power and to stopping violence (The Economist 2012).

Similarly to Tajikistan, Kyrgyzstan's economic development was hindered by several factors already as a Soviet republic, primarily its isolated geographical position and the scarcity of its natural resources, including fossil fuels. It is perhaps due to this, that despite all its positive and negative effects, Soviet forced industrialization made less of an impact on Kyrgyzstan's economy than on a number of other republics. Although here too the proportion of arable land is small, the weight of nomad animal husbandry continues to be considerable. Up to our days, agriculture employs nearly 40 per cent of the Kyrgyz population, providing at least one third of the republic's GDP (World Bank 2012b: 6).

Kyrgyzstan's main source of fuel is traditionally Russia, while an increasing proportion of consumer goods is imported from China. In 2000-2010 exports increased by no more than 29 per cent, while its imports increased 2.5 -fold. As a result, the country where in the early $2000 \mathrm{~s}$ exports and imports were balanced has accumulated a foreign trade deficit of more than 10 per cent of the GDP, which it manages to finance through the remittances of growing numbers of Kyrgyz guest workers and expanding informal re-exportation. Because of the mushrooming imports, the Kyrgyz economy's openness has also grown, reaching 40 or 50 per cent of the GDP.

Since its independence, in Kyrgyzstan too only two sectors, namely the gold industry and hydroelectric power, have attracted sizeable international investment. The most important one off investment was a result of the agreement with the Cameco consortium about extracting the gold of the Kumtor site, which is located at more than 4,000 $\mathrm{m}$ above sea level and is hard to access. According to the concession, the Kyrgyz state is entitled to 70 per cent of the profits, amounting to 26 per cent of the full Kyrgyz budget and 40 per cent of the country's exports (World Bank 2012b: 9).

In Central Asia, it is probably Kyrgyzstan's foreign trade that is impacted by reexportation the strongest. Informal cross border trade of cheap Chinese consumer goods, not even featuring in statistics, plays a major part in this. The main items of formal re-exportation are pieces of machinery and technical equipment, and fuel. One factor explaining the formerly 
considerable Kyrgyz fuel re-export had been the need to supply fuel to the Manas American transit center, which however was closed down in 2014. The second factor why Kyrgyzstan, poor in fossil and hydrocarbon fuels, has become the main regional distribution center of these goods is that due to the close Russian-Kyrgyz relations, it obtains Russian petrol, diesel oil and kerosene at lower prices than its neighbors, especially Uzbekistan. Kyrgyz fossil energy exportation is probably the re-exportation of Russian imports, since not only the stocks of crude oil and natural gas but also the country's refining capacities are very limited (Mogilevskii 2012: 20).

Besides the expanding formal and informal re-exportation, international aid and guest workers' remittances have been the main sources of the Kyrgyz rentier economy. In 2007, guest workers' remittances amounted to 27 per cent of the Kyrgyz GDP, the fourth highest percentage in the world (Marat 2009: 8). From 2000, the American military base at the Manas airport near Bishkek, established as part of the action again Afghanistan, was a significant source of foreign currency for the Kyrgyz government.

Table 3. Annual per capita fuel/mineral export income in Central Asian states

\begin{tabular}{|l|c|c|}
\cline { 2 - 3 } \multicolumn{1}{c|}{} & \multicolumn{2}{c|}{$\begin{array}{c}\text { Per capita fuel/mineral export income in Central Asian states } \\
\text { (USD) }\end{array}$} \\
\cline { 2 - 3 } & $\mathbf{2 0 0 0}$ & $\mathbf{2 0 1 0}$ \\
\hline Kazakhstan & 571 & 3627 \\
\hline Kyrgyzstan & 49 & 269 \\
\hline Tajikistan & 76 & 91 \\
\hline Turkmenistan & 353 & 2804 \\
\hline Uzbekistan & 14 & 154 \\
\hline
\end{tabular}

Source: COMTRADE, Agency of Statistics of the RK, Agency on Statistics of the RT, National Statistical Committee of the KR, State Committee of the RU on Statistics, State Committee of Turkmenistan on Statistics, and the author's calculations based on Mogilevskii's 2012 data.

In the light of these data, it seems that Turkmenistan is the only republic that fully meets the definition of a "rentier state." For Kazakhstan the picture is somewhat more nuanced, but it is also close to the ideal type of the "rentier state." (It is hardly accidental that it is in these two countries that we find by far the highest per capita hydrocarbon/mineral export revenues.) At the same time, Kyrgyzstan and Tajikistan, poor in raw materials but largely dependent on outside resources, fit the analytical category of the "semi-rentier" state (Ostrowski 2011: 286). Unlike Ostrowski, however, I argue that as reflected by foreign trade statistics, Uzbekistan does not meet the criteria of the rentier state, not even those of the rentier economy; on the 
contrary, it seems to be a clearly closed national economy aimed at autarky, ${ }^{3}$ although Uzbek elite groups are visibly guided by a kind of rent-hunting logic.

\section{Personality-centred politics and the authoritarian exercise of power}

In the literature dealing with Central Asia, qualifying the authoritarian political systems of post-Soviet Central Asian republics as "neo-patrimonial"" is widely accepted (Collins 2006; Cummings 2002; Ishimaya 2002). In them, political power is carried by individuals and interpersonal patronage networks, rather than bureaucratic institutions. Henceforth, for the sake of simplicity these are labelled as "clans". Typically, neopatrimonial regimes do not have a solid political ideology either. The basic dynamics of political processes are defined by the logic of the patron-client relationship: public offices may be won in return for personal services, as if they were rewards in exchange for which the clients are supposed to mobilize the required number of voters for their patron at the time of elections. As Ishimaya highlights the emergence of neopatrimonial regimes in periods of political transition when there is no solid institutional background is almost typical in case of liberated former colonies. The development of a rentier economy may be a factor enhancing the neopatrimonial character of political regimes, since patronage networks related to the political leader(s) constitute the primary mediating channel between outside earnings and the domestic economy (Ishimaya 2002: 43-45).

In respect of their constitutional setup, measured by the Krouwel scale, ${ }^{5}$ four of the five republics clearly fall into the category of presidential rather than parliamentary governments. Following the 2010 Revolution and constitutional reform, Kyrgyzstan changed to the parliamentary form of government, but the president's powers are still considerably stronger

\footnotetext{
${ }^{3}$ This is the case even if in addition to export revenues of hydrocarbon fuels and other minerals, in Uzbekistan the revenues from the cotton sector and cotton exportation are also seen as rentier sources, as the work is typically done in agricultural cooperatives using day labourers and free student labour, which is close to employing slave labour (Acemoglu - Robinson 2012: 391-395). Even if our calculations use data modified by the incomes of the cotton exports, no more than 10-15 per cent of the Uzbek GDP originates from exporting raw materials.

"Neo" as a prefix indicates that unlike with traditional patrimonial systems, in neopatrimonial regimes traditional legitimating forms and dynastic heritage do not necessarily contribute to constituting political power (Ishimaya 2002).

5 According to the Krouwel method, countries examined are awarded plus and minus points based on the presidential or parliamentary features of their constitutional structure. Thus on the Krouwel scale, -10 means the "idealtypical parliamentary" structure, while +10 indicates the "idealtypical presidential structure." If a country scores in the negative zone, it is closer to the parliamentary, while if it scores in the positive zone, it is closer to the presidential model (Krouwel 2003). In our days, Kazakhstan, Tajikistan and Turkmenistan score $+8,+6$ and +6 respectively, while since the 2011 constitutional changes Uzbekistan scores only +4 , and since the 2010 parliamentary reforms Kyrgyzstan scores +1 (Borisov 2011:63).
} 
than usual for heads of state in parliamentary systems. The presidents' political influence goes beyond their constitutional powers. Thus in agreement with Borisov, it is argued that in the Central Asian context presidential government is the expression of a personality-centred exercise of power rather than its cause (Borisov 2011). For the type of their political structure, the regimes concerned may be described primarily as neo-patrimonial, personality-centred presidential dictatorships rather than party states or military dictatorships.

All five countries have constantly low democracy indices. In fact, over the past 25 years, they have not met even the minimalist democracy criteria. In light of international reports by organisations such as OSCE, Central Asian parliamentary and presidential elections have not been free and fair, and in many cases not even competitive. The only possible exceptions are the 2010 and 2011 Kyrgyz parliamentary and presidential elections, which observers have qualified as free and fair (OSCE $2010 \mathrm{a}, \mathrm{b}$ ) and about which the head of the OSCE election observers said that it [i.e. the 2010 parliamentary election] had been the first in the Central Asian region where the outcome was not fully predictable (Huskey - Hill 2013: 238). The most widely known indicators of the concept of minimalist democracy are the country reports in Freedom in the World, the annual Freedom House publication. ${ }^{6}$

Table 4. Political and civil rights in the Central Asian republics

\begin{tabular}{|c|c|c|c|c|c|c|c|c|c|c|}
\hline & \multicolumn{2}{|c|}{2010} & \multicolumn{2}{c|}{2011} & \multicolumn{2}{c|}{2012} & \multicolumn{2}{c|}{2013} & \multicolumn{2}{|c|}{2014} \\
\hline & $\begin{array}{c}\text { Polical } \\
\text { rights }\end{array}$ & $\begin{array}{c}\text { Civil } \\
\text { liberties }\end{array}$ & $\begin{array}{l}\text { Polical } \\
\text { rights }\end{array}$ & $\begin{array}{c}\text { Civil } \\
\text { liberties }\end{array}$ & $\begin{array}{c}\text { Polical } \\
\text { rights }\end{array}$ & $\begin{array}{c}\text { Civil } \\
\text { liberties }\end{array}$ & $\begin{array}{c}\text { Polical } \\
\text { rights }\end{array}$ & $\begin{array}{c}\text { Civil } \\
\text { liberties }\end{array}$ & $\begin{array}{c}\text { Polical } \\
\text { rights }\end{array}$ & $\begin{array}{c}\text { Civil } \\
\text { liberties }\end{array}$ \\
\hline Kazakhstan & 6 & 5 & 6 & 5 & 6 & 5 & 6 & 5 & 6 & 5 \\
\hline Kyrgyzstan & 6 & 5 & 5 & 5 & 5 & 5 & 5 & 4 & 5 & 4 \\
\hline Tajikistan & 6 & 5 & 6 & 5 & 6 & 5 & 6 & 6 & 6 & 6 \\
\hline Turkmenistan & 7 & 7 & 7 & 7 & 7 & 7 & 7 & 7 & 7 & 7 \\
\hline Uzbekistan & 7 & 7 & 7 & 7 & 7 & 7 & 7 & 7 & 7 & 7 \\
\hline
\end{tabular}

Source: Freedom House(2014)

\footnotetext{
${ }^{6}$ The 195 countries examined today are graded for political and civil rights. Freedom House's "political rights" may be regarded as the empirical expression of the most minimalist democracy concept. This aggregates indicators of three areas: 1. the election process, 2. political pluralism and participation and 3. the functioning of government. "Civil rights" embrace four categories: 1. freedom of expression; 2. freedom of assembly and political organisation; 3.rule of law and 4. personal autonomy and rights. Taking the average of the two indicators if the score is 1 to 2.5 , the state is free; if it is 3 to 5 , it is partially free; and if the score is 5 to 7 , the state is not free.
} 
The Economist Intelligence Unit (EIU) analysts have been working with the The Economist since 2006, conducting similar monitoring as the Freedom House country reports. The EIU acknowledges that it intends to measure and operationalize a wider concept of democracy than does Freedom House. Their "democracy index" is an aggregate of over 60 indicators based on the World Values Survey, Eurobarometer and Gallup polls. According to these, countries are placed into four categories: 1. full democracies (8-10 points); 2. flawed democracies (6-7.9 points); 3. hybrid regimes (4-5.9 points); 4. authoritarian regimes (scores below 4). The fundamental difference between full and flawed democracies is in the quality of government and political culture, while in hybrid and authoritarian regimes the freedom and fairness of elections and human liberties are also affected. Based on this democracy index, four Central Asian republics are regarded as authoritarian, while Kyrgyzstan is a hybrid regime. These qualifications are generally in line with the Freedom House evaluations.

Table 5. The evaluation of Central Asian countries based on the EIU Democracy Index

\begin{tabular}{|c|r|r|r|r|r|r|r|}
\hline & \multicolumn{1}{|c|}{$\mathbf{2 0 0 6}$} & \multicolumn{1}{|c|}{$\mathbf{2 0 0 8}$} & \multicolumn{1}{|c|}{$\mathbf{2 0 1 0}$} & \multicolumn{1}{|c|}{$\mathbf{2 0 1 1}$} & \multicolumn{1}{c|}{$\mathbf{2 0 1 2}$} & \multicolumn{1}{|c|}{$\mathbf{2 0 1 3}$} & \multicolumn{1}{c|}{$\mathbf{2 0 1 4}$} \\
\hline Kazakhstan & 3.17 & 3.04 & 2.95 & 3.24 & 3.03 & 3.45 & 3.62 \\
\hline Kyrgyzstan & 5.24 & 4.69 & 4.69 & 4.34 & 4.31 & 4.05 & 4.08 \\
\hline Tajikistan & 2.37 & 2.51 & 2.51 & 2.51 & 2.51 & 2.45 & 2.45 \\
\hline Turkmenistan & 1.83 & 1.72 & 1.72 & 1.72 & 1.72 & 1.72 & 1.83 \\
\hline Uzbekistan & 2.45 & 1.72 & 1.72 & 1.74 & 1.74 & 1.74 & 1.85 \\
\hline
\end{tabular}

Source: EIU (2014).

\section{Regime stability and its indicators}

Issues of political stability and instability seem to have even more varied indicators in the literature than political democracy. Alesina, Ozler, Roubini and Swagel define political instability as constitutional or unconstitutional change(s) in the exercise of executive power (Alesina et al. 1996). Roberto Perotti and Robert J. Barro focus primarily on political violence when defining the degree of regime stability, and suggest that the number of revolutions, coups, political attempts and terrorist attacks should be considered (Barro 1991; Perotti 1996). In contrast, Air Aisen and Francisco Vega understand political instability as the frequency of government crises and cabinet changes (Aisen and Vega 2011: 3). Regarding these factors, Kyrgyzstan and Tajikistan seem much more instable than the other three. We 
should not forget that in the 1990s there was a ravaging regionally-based civil war in the former, and violent rioting broke the ruling regime in 2005 and 2010. Although Uzbekistan did not have a similarly violent regime change, on the regional level in 2005 too there were uprisings in the Ferghana Valley.

The concepts described focus on effective (violent or constitutional) changes in the political system or regime, or more precisely, on the frequency of these events. This however does not necessarily inform us about a political system's potential fragility. The Fragile States Index (earlier Failed States Index) of the American Fund for Peace think tank, aggregating 12 indicators intends to grasp this fragility. Six of the 12 indicators are more of a socio-economic character, while the other six try to quantify political and security risks. ${ }^{7}$

Table 6. The 2014 evaluation of Central Asian republics based on the 12 indicators of the FFP FSI Index

\begin{tabular}{|c|c|c|c|c|c|c|}
\hline & $\begin{array}{c}\text { Demographic } \\
\text { Pressures }\end{array}$ & $\begin{array}{l}\text { Refugees } \\
\text { and IDP's }\end{array}$ & $\begin{array}{c}\text { Group } \\
\text { Grievance }\end{array}$ & $\begin{array}{l}\text { Human - } \\
\text { flight \& } \\
\text { Brain Drain }\end{array}$ & $\begin{array}{c}\text { Uneven } \\
\text { Economic } \\
\text { Develpoment }\end{array}$ & $\begin{array}{l}\text { Poverty and } \\
\text { Economic } \\
\text { Decline }\end{array}$ \\
\hline Kazakhstan & 5.1 & 3.8 & 6.5 & 3.9 & 5 & 5.9 \\
\hline Kyrgyzstan & 6 & 5.5 & 8.2 & 6.1 & 6.7 & 7.3 \\
\hline Tajikistan & 7.5 & 5.1 & 7 & 6.1 & 5.9 & 7.7 \\
\hline Turkmenistan & 6 & 4.2 & 6.9 & 5.1 & 6.7 & 5.3 \\
\hline \multirow[t]{3}{*}{ Uzbekistan } & 6.4 & 5.7 & 7.4 & 6.6 & 7.3 & 7.1 \\
\hline & & & & & & \\
\hline & $\begin{array}{c}\text { State } \\
\text { Legitimacy }\end{array}$ & $\begin{array}{l}\text { Public } \\
\text { Services }\end{array}$ & $\begin{array}{l}\text { Human } \\
\text { Rights and } \\
\text { Rule of } \\
\text { Law }\end{array}$ & $\begin{array}{l}\text { Security } \\
\text { Apparatus }\end{array}$ & $\begin{array}{l}\text { Factionalized } \\
\text { Elites }\end{array}$ & $\begin{array}{c}\text { External } \\
\text { Interventio } \\
\mathbf{n}\end{array}$ \\
\hline Kazakhstan & 7.7 & 4.8 & 7.2 & 6 & 7.6 & 5 \\
\hline Kyrgyzstan & 8.2 & 5.9 & 7.3 & 7.1 & 8 & 7.6 \\
\hline Tajikistan & 9 & 6.2 & 7.9 & 7.1 & 8.4 & 6.7 \\
\hline
\end{tabular}

\footnotetext{
${ }^{7}$ It needs to be noted here that the professional reception of the FSI is not unanimous. As pointed out by critics, for example Tamás Csiki, it makes one think that in the light of the FSI scores, two thirds of the world's countries are highly fragile and drifting towards state failure (Csiki 2009: 93), with such politically clearly repressive but at the same time extremely strong powers as Russia and China among them. This begs the question whether the criteria have not been too strict (Marsai 2014). Others argue that it is absurd that because of the focus of indicators that intend to highlight potential instability, countries where an effective civil war is raging (e.g. Syria) get better evaluation than definitely poor and vulnerable, but peaceful countries, such as Kenya (Ross 2013).In response to these critiques, the developers of the FSI have said that although the index puts state function into its focus, the categories they use for assessment belong to the field of human security. This index is supposed to reflect the state's stability, as well as its citizens' human security. This is why countries with a strong status apparatus, such as China, may fall into a relatively weaker category, because centralised public governance is often coupled with repressive, authoritarian trends that increase the individual's vulnerability and question the rule of law (Marsai 2014).
} 


\begin{tabular}{|c|r|r|r|r|r|r|} 
Turkmenistan & 9.6 & 6.4 & 8.5 & 6.8 & 7.8 & 4.9 \\
\hline Uzbekistan & 9.3 & 5.4 & 9.3 & 7.6 & 8.8 & 5.4 \\
\hline
\end{tabular}

Source: Fund for Peace

In the present study, special attention is given to the World Bank's World Governance Index (WGI) measuring political stability by using primarily opinion polls (e.g. World Economic Forum Global Competitiveness Survey) and analyses of international risk analysis companies and organisations (e.g. PRS International Country Risk Guide; Cingranelli - Richards Human Rights Database and International Terror Scale, etc.). Critics of the WGI methodology argue that these calculations express citizens' and analysts' expectations rather than the objective degree of political violence and instability (Arndt and Oman 2008; Thomas 2009; Langbein and Knack 2010). According to the WGI data, Turkmenistan and Kazakhstan seem politically most stable, while the other three are less so, which is hardly surprising if we consider the 2005 and 2010 Kyrgyz revolutions and the 2005 Andijan unrest.

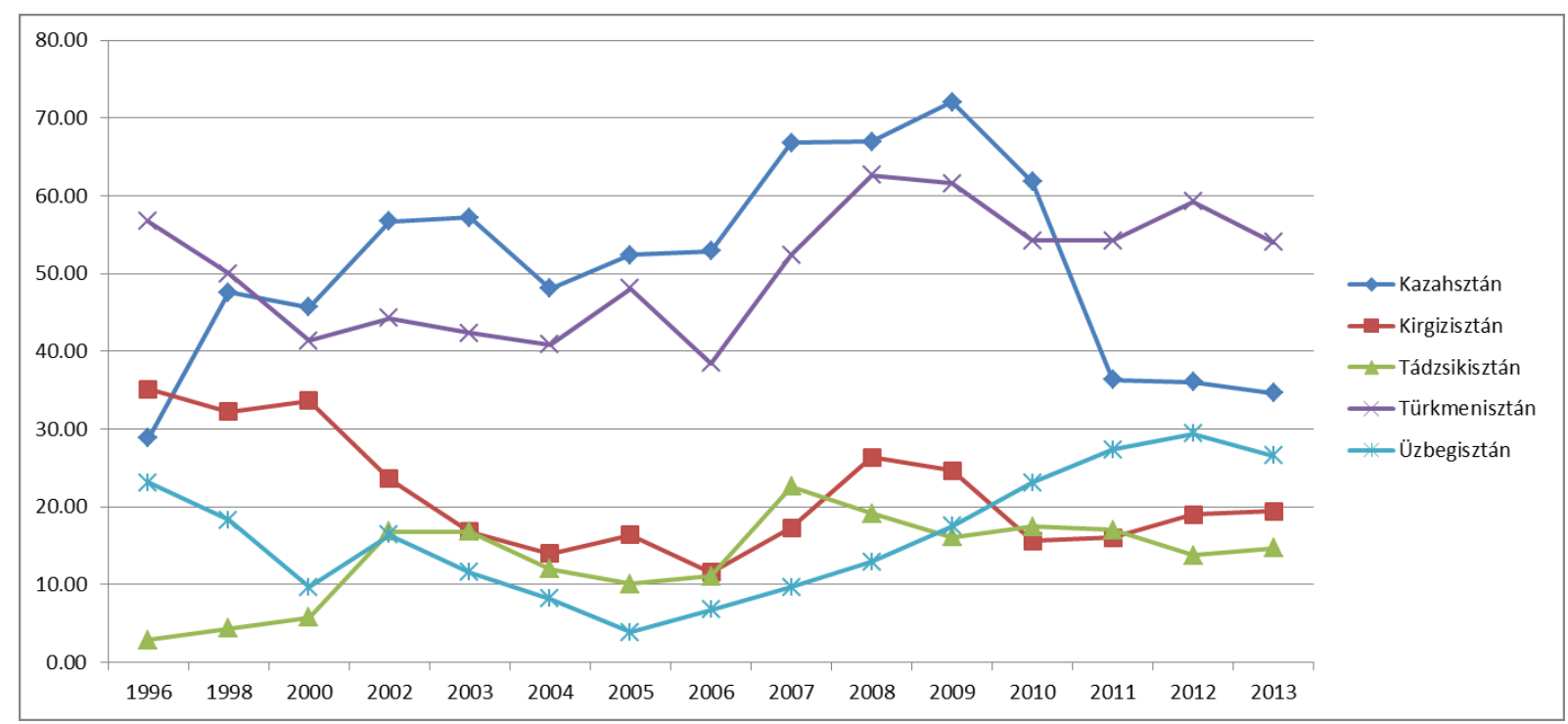

Figure 1. Central Asian republics WGI political stability index 1996-2013

Source: World Bank

\section{Conclusions}


When comparing the indicators for regime stability and political democracy Central Asian republics constitute a rather homogeneous block and show very weak results both for the democratic exercise of power and political stability. In this respect, Kyrgyzstan may be an exception whose political stability indicators are much worse than those for democracy. To some extent, Kazakhstan and Turkmenistan are also exceptions, as the character of exercising power is similar to what we see in the other Central Asian republics, but politically they seem somewhat more stable.

As far as the character of exercising power, or the dimensions of democracy and autocracy, Central Asian republics' positions are not very varied: four of the five are clearly in the autocratic spectrum. Although in the early 1990s the expectations were not unfounded that the Central Asian republics would eventually split into a politically more liberal (Kazakhstan and Kyrgyzstan) and an authoritarian block (Uzbekistan, Turkmenistan and Tajikistan). This idea may have seemed attractive also because it echoed a civilizational fault line between the former steppe zone and Transoxania. In the same way as the Soviet modernization swept away the old civilizational fault line between the Steppe Region and Transoxania, we can no longer talk of the liberal-authoritarian fault line, if it ever existed at all. The Kazakh autocracy is less and less "liberal" and has greatly assimilated to the "standard Central Asian model". As evaluated by Freedom House, neither did the 2010 Kyrgyz parliamentary turn- at least in such a short run - lead to a significant shift towards democratization. The EIU democracy index shows more divergence for Kyrgyzstan: especially in its electoral process and participation, the country has had much higher scores in recent years than the other Central Asian republics. At the same time, the quality of political culture and the efficiency of government have not shown similar improvement. Neither did switching to parliamentary government and a competitive multi-party system make the Kyrgyz system more stable overnight. Based on the indicators described, it is still among the potentially more instable political systems. In the dimension of regime stability vs. lability, the FSI index shows very little divergence between the five countries: they all fall into the endangered category and should be given a "warning". The WGI index, however, shows more marked differences: Kazakhstan and Turkmenistan seem to be politically more stable autocracies, while Kyrgyzstan, Tajikistan and Uzbekistan are - at least potentially - more instable political systems.

The puzzle raised as the starting point of this paper was how the possible differences in exercising power and regime stability appear to be related to the rentier nature of the state, or its absence. It appears that those regimes prove to be more stable that are closest to the 
conceptual ideal type of the rentier state", namely the hydrocarbon exporting Turkmenistan and Kazakhstan. Although as we have seen, the political elites of the other three regimes are also characterised by the rent-seeking logic, their countries are not rentier states, but rentier economies at best (although in the case of the strongly self-dependent Uzbekistan, even this label is questionable).

Unlike Wojciech Ostrowski, I would argue that in the case of central Asian republics, the autocratic exercise of power is not necessarily due to their rentier nature. There are more repressive and more liberal rentier states, and among the non-rentier regimes, Uzbekistan is as autocratic as Turkmenistan. It seems however, that in the Central Asian context there is a relationship between a state's rentier nature and political stability. Of the regimes guided by the rentier logic, those that are rich in natural resources, as Kazakhstan and Turkmenistan are clearly doing better as far as their political stability is concerned than those that possess meagre resources, namely Kyrgyzstan and Tajikistan.

As far as the correlation of the rentier character and regime stability is concerned, their deeper interrelations are varied. One obvious casual mechanism identified is what we call alimentative social policy, which can be observed in Arab and Latin-American rentier states as well. This distinctive welfare mix consists hangovers from the paternalistic Soviet welfare system like the free use of public transport, the subsidization of staple foods and populist ad hoc benefit payments mostly at the context of elections (Gawrich - Franke 2011b: 88). The Turkmen regime has spent state earnings generated by the state controlled gas sector mainly on wide-ranging price subsidies for the public and social benefits. Since 1993, the Turkmen state has provided free drinking water, gas and electric energy to its citizens. In addition, the agricultural sector based on monocultural cotton production and employing some 50 per cent of the work force is still mainly subsidised from natural gas revenues ${ }^{8}$ (Pomfret 2006: 90-97).

In Kazakhstan we observe a similar strategic and paternalistic use of social policy. According to the presidential address to the Kazakhstani people in February 2008, budgetary allocations for education, health care and social security have grown more than fivefold since 2000 (Gawrich - Franke 2011b: 91).

Table 7. Government spending as a percentage of GDP by country

\begin{tabular}{|l|l|l|}
\hline & 2000 & 2010 \\
\hline
\end{tabular}

\footnotetext{
${ }^{8}$ Despite heavy subsidies to the agrarian sector, the country has to import nearly 70 per cent of basic foodstuffs. Because of forced irrigation, Turkmenistan's limited arable land is strongly affected by salinization. Thus, food shortages were not infrequent in the 1990s (Ochs 1997, 343).
} 


\begin{tabular}{|c|c|c|} 
Kazakhstan & $13.72 \%$ & $23.70 \%$ \\
\hline Kyrgyzstan & $15.80 \%$ & $21.14 \%$ \\
\hline Tajikistan & no data & $26.10 \%$ \\
\hline Turkmenistan & no data & $9.30 \%$ \\
\hline Uzbekistan & no data & $32.20 \%$ \\
\hline
\end{tabular}

Source: CEIC Global Database and the author's calculations based on World Bank WDI indicators and CIA Factbook data

However, as seen in table 5, in the Central Asian republics government spending, with welfare and military expenses included, are not extremely high as compared to the GDP, because in the oil countries of the Middle East and western European welfare states, they are considerably higher. What is more, based on statistical data, it is the rentier type regimes in Central Asia that have relatively the lowest government spending. (Naturally, this does not mean to say that in absolute figures the welfare expenses of Kazakhstan, Turkmenistan and even Uzbekistan do not considerably exceed those of Tajikistan.) I would argue that the regime stabilising mechanism of the Kazakh or Turkmen rentier states does not primarily work through their welfare or military spending as indicated also in the government's official statistics. The revenues of exporting oil, natural gas and other minerals are utilised much more through the channels of clan-based patronage networks.

After gaining independence, the political trajectory of Central Asian republics was defined by the dynamics of the regionally affiliated clans' competition. The stability of Central Asian regimes was guaranteed by informal pacts ensuring some kind of balance between the politically and economically stronger "clans" or political fractions (Collins 2006: 51-53). The cornerstone of these inter-clan pacts is a balanced division of state patronage positions and incomes. A decrease or sudden drying up of external sources of revenues may aggravate the fight for power between clans, and may even lead to a dramatic loss of balance in inter-clan pacts. This is demonstrated by the examples of Tajikistan and Kyrgyzstan where informal political fractions saw the state almost exclusively as the source of patronage incomes. As in Tajikistan right after the collapse of the Soviet Union, and in Kyrgyzistan a little later, starting from the late 1990s these started drying up, the fight between clans became fiercer for control over the dwindling political and economic resources. In Tajikistan this led to the breakout of an open civil war, while in Kyrgyzstan to two violent regime changes. In case of Uzbekistan, a country relatively rich in natural resources, this instability for the moment means potential fragility only. In Kazakhstan and Turkmenistan, it seems that the 
regime consolidation based on a division of rentier incomes can be maintained in the long run. The causal relations of a state's rentier character and clan-based regime stability offer a promising direction for future research in the framework of post-Soviet Central Asian political systems.

\section{References}

Acemoglu, D. - Robinson, J. A. (2012): Why nations fail? The origins of power, prosperity and poverty. New York: Crown Business.

Afanasyeva, A. (2012): Kashagan's big oil coming to market in mid-2013. Reuters 2012.08.10. http://www.reuters.com/article/2012/08/10/kazakhstan-oil-kashaganidUSL6E8J7CML20120810, accessed: 15.03.2015.

Aisen, A. - Vega, F. J. (2011): How Does Political Instability Affect Economic Growth? IMF Working Paper 1112.

Alesina, A. - Ozler, S. - Roubini, N. - Swagel, P. (1996): Political instability and economic growth. Journal of Economic Growth 1(2): 189-211.

Anderson, B. - Klimov, J. (2012): Uzbekistan: Trade Regime and Recent Trade Developments, Central Asian University. http://www.ucentralasia.org/downloads/UCAIPPA-WP4-Uzbekistan\%20and\%20Regional\%20Trade.pdf, accessed: 26.11.2014.

Arndt, C. - Oman C. (2008): The Politics of Governance Ratings. Maastricht University Working Paper. http://www.maastrichtuniversity.nl/web/show/id=4416424/langid=42, accessed: 05.03.2015.

Radio Free Europe (2014): Atambaev Says No Foreign Troops At Manas After 2014. http://www.rferl.org/content/kyrgyzstan_president_says_no foreign troops_manas 201 4/24490080.html, accessed: 24.02.2014.

Barro, R. J. (1991): Economic growth in a cross section of countries. The Quarterly Journal of Economics 106(2): 407-443.

Beblawi, H. (1990): The Rentier State in the Arab World. In: Luciani, G. (ed.): The Arab State. Berkeley and Los Angeles: University of California Press

Borisov, N. (2011): The institution of presidency in the Central Asian countries: personalization vs. institutionalization. Central Asia and the Caucasus 12(4): 57-66.

Colgan, J. D. (2015): Oil, domestic conflict and opportunities for democratization. Journal of Peace Research 52(1) 3-16. 
Collier, P. - Hoeffler A. (2000): Greed and Grievance in Civil War. The World Bank Development Research Group

Collins, K. (2006): Clan Politics and Regime Transition in Central Asia. Cambridge: Cambridge University Press

Cummings, S. (2002): Power and change in Central Asia. In: Cummings, S. (ed.): Power and change in Central Asia. London and New York: Routledge

Csiki, T. (2009): A Failed States Index 2009. Nemzet és Biztonság - Biztonságpolitikai Szemle 7(2): 87-93.

de Soysa, I. (2000): The Resource Curse: Are Civil Wars Driven by Rapacity or Paucity? In: Berdal, M. - Malone, D. M. (eds): Greed and Grievance. Economic Agenda in civil Wars. Boulder and London: Lynne Rienner.

The Economist (2012): Drugs in Tajikistan. Heroin stabilises a poor country. http://www.economist.com/node/21553092, accessed: 23.02.2014.

Erlich, A (2006): Tajikistan: From Refugee Sender to Labor Exporter. Migration Policy Institute. http://www.migrationinformation.org/Feature/display.cfm?id=411, accessed: 23.02. 2014.

Frye, T. (1997): A Politics of Institutional Choice: Post-Communist Presidencies. Comparative Political Studies 30(5): 523-552.

Gawrich, A. - Franke, A. (2011a): Introduction. In: Gawrich, A. - Franke, A. - Windwehr, J. (eds): Are Resources a Curse? Rentierism and Energy Policy in Post-Soviet States. Opladen, Farmington Hills: Barbara Budrich Publishers.

Gawrich, A. - Franke, A. (2011b): Autocratic Stability and Post-Soviet Rentierism: the Cases of Azerbaijan and Kazakhstan. In: Gawrich, A. - Franke, A. - Windwehr, J. (eds.): Are Resources a Curse? Rentierism and Energy Policy in Post-Soviet States. Opladen, Farmington Hills: Barbara Budrich Publishers.

Ishimaya, J. (2002): Neopatrimonialism and the prospects for democratization in the Central Asian republics. In: Cummings, S. (ed.): Power and change in Central Asia. London and New York: Routledge

Krouwel, A. (2003): Measuring presidentialism of Central and East European countries. $V U$ Amsterdam Political Science Porking Papers. http://www.fsw.vu.nl/en/Images/Measuring\%20presidentialism\%20of $\% 20$ Central $\% 20 \mathrm{a}$ nd\%20East\%20European\%20countries_tcm31-42727.pdf, accessed: 10.02.2014.

Langbein, L. - Knack, S. (2010): The Worldwide Governance Indicators: Six, One, or None? The Journal of Development Studies 46(2): 350-370. 
Le Billon, P. (2001): The political ecology of war: natural resources and armed conflicts. Political Geography 20: 561-584.

Luciani, G. (1990): Allocation vs. Production States: A Theoretical Framework. In: Luciani, G. (ed.): The Arab State. Berkeley and Los Angeles: University of California Press.

Marsai, V. (2014): A 2014-es jubileumi Fragile (Failed) States Index és tanulságai [The 2014 Failed States Index and its main findings]. NKE Sratégiai Védelmi Kutatóközpont Elemzések - 2014/16.

Mogilevskii, R. (2012): Trends and Patterns in Foreign Trade of Central Asian Countries. University of Central Asia, Institute of Public policy and Administration Working Paper.

Nazriev, S. - Manzarshoeva, A. (2009): Poverty Tajikistan's only growth area. Asia Times

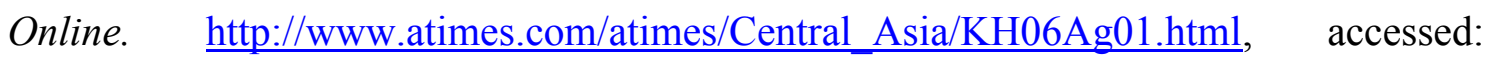
2014.02.23.

Ochs, M. (1997): Turkmenistan: the quest for stability and control. In Dawisha, K. - Parrott, B. (eds.): Conflict, cleavage and change in Central Asia and the Caucasus. Cambridge: Cambridge University Press.

Olcott, M. B. (2005): Central Asia's Second Chance. Carnegie Endowment for International Peace.

Olcott, M. B. (2010): Kazakhstan: Unfulfilled Promise? Carnegie Endowment For International Peace.

OSCE (2010): Активные и плюралистические парламентские выборы создают основу для дальнейшего укрепления демократии [Active and pluralistic parliamentary elections provide a basis for further strengthening of democracy]. http://www.osce.org/ru/odihr/72026, accessed: 04.11. 2014.]

OSCE (2011): Kyrgyzstan's presidential election was peaceful, but shortcomings underscore need to improve integrity of process. http://www.osce.org/odihr/elections/84571, accessed: 01.02. 2014.

Ostrowski, W. (2011): Rentierism, Dependency and Sovereignty in Central Asia. In: Cummings, S. and Hinnebush, R. (eds.): Sovereignty after empire: comparing the Middle East and Central Asia. Edinburgh: Edinburg University Press.

Perotti, R. (1996): Growth, income distribution and democracy: What the data say. Journal of Economic Growth 1(2): 149-187.

Pomfret, R. (2006): The Central Asian Economies since Independence. Princeton: Princeton University Press 
Roeder, P. G. (1994): Varieties of Post-Soviet Authoritarian Regimes. Post-Soviet Affairs 10(1): 61-101.

Ross, E. (2013): Failed states are a western myth. The Guardian, 28 June.

Ross, M. L. (1999): The Political Economy of the Resource Curse. World Politics 51: 297322.

Ross, M. L. (2001): Does Oil Hinder Democracy? World Politics 53: 325-361.

Smith, B. (2015): Resource wealth as rent leverage: Rethinking the oil-stability nexus. Conflict Management and Peace Science, published online before print, November 3, doi: 10.1177/0738894215609000 1-21.

Spechler, D. R. - Spechler, M. C. (2009): Uzbekistan among the great powers. Communist and Post-communist Studies 42(3): 353-373.

Thomas, M. (2009): What Do the Worldwide Governance Indicators Measure? European Journal of Development Research 22(1): 31-54.

U.S. Energy Information Administration (2014): Turkmenistan http://www.eia.gov/countries/cab.cfm?fips=TX, accessed: 22.02.2014.

World Bank (2012a): Country Brief Tajikistan.

http://web.worldbank.org/WBSITE/EXTERNAL/COUNTRIES/ECAEXT/TAJIKISTA NEXTN/0,,contentMDK:20630697 menuPK:287255 pagePK:141137 piPK:141127 t heSitePK:258744,00.html, accessed: 23.02.2014.

World Bank (2012b): Kyrgyz Republic Partnership Program Snapshot. http://siteresources.worldbank.org/INTKYRGYZ/Resources/KR_Snapshot_March2012 final.pdf, accessed: 23.02.2014. 